\title{
SUPPRESSED INNATE IMMUNE RESPONSE AGAINST MAMMARY CARCINOMA IN BALB/C MICE
}

\author{
Ivan Jovanovic, Gordana Radosavljevic, Marija Milovanovic, Katerina Martinova, Nada Pejnovic, Nebojsa Arsenijevic, Miodrag L. Lukic \\ Centre for Molecular Medicine and Stem Cell Research, Faculty of Medicine, University of Kragujevac, Serbia

\section{SUPRIMIRANI URODJENI IMUNSKI ODGOVOR TUMORA DOJKE KOD BALB/C MIŠEVA}

Ivan Jovanović, Gordana Radosavljević, Marija Milovanović, Katerina Martinova, Nada Pejnović, Nebojša Arsenijević, Miodrag L. Lukić Centar za molekulsku medicinu I istraživanje matičkih ćelija, Fakultet medicinskih nauka, Univerzitet u Kragujevcu, Srbija

\begin{abstract}
Breast carcinoma is one of the leading causes of deaths among women worldwide. The immune response in breast cancer is mediated by innate and adaptive immune cells, including natural killer (NK) cells, dendritic cells (DCs) and T lymphocytes. The $4 T 1$ mammary carcinoma line derived from $B A L B / c$ mice shares many characteristics with naturally occurring human breast cancer. We aimed to investigate the mechanisms of anti-tumour immunity using the experimental $4 T 1$ breast cancer model in syngeneic $B A L B /$ c mice. After 12 days of tumour inoculation, mammary carcinoma-bearing mice had significantly decreased numbers of $N K p 46^{+} \mathrm{NK}$ cells compared with healthy mice and lower cytotoxic activity of total splenocytes and NK cells in vitro. Additionally, significantly higher numbers of $C D 11 c^{+} D C s$ were detected in the spleens of tumour-bearing mice, but the number of activated $\mathrm{CD} 8 \mathrm{O}^{+} \mathrm{CD} 86^{+}$dendritic cells was entwithsimilar to that in healthy mice, indicating an increased number of immature DCs in tumour-bearing mice. The data indicate that $4 T 1$ mammary carcinoma progression in $B A L B / c$ mice is associated with suppressed innate anti-tumour immunity.
\end{abstract}

Keywords: $4 T 1$ mammary carcinoma, $B A L B / c$ mice, NK cells, dendritic cells.

\section{APSTRAKT}

Rak dojke je jedan od najčešćih uzroka smrti žena, širom sveta. Imunski odgovor na tumor dojke posredovan je ćelijama urođene i stečene imunosti, uključujući ćelije ubice (NK), dendritske ćelije (DCs) i T limfocite. 4T1 mišji karcinom dojke, dobijen iz BALB/C miša, deli mnoge karakteristike sa spontano nastalim humanim karcinomom dojke. Cilj istraživanja je bio ispitati mehanizme anti-tumorske imunosti koristeći 4T1 eksperimentalni model tumora dojke singen sa $B A L B / c$ miševima. Dvanaest dana nakon inokulacije tumora, miševi sa tumorom imali su značajno manji broj NKp46+ NK ćelija, u poređenju sa zdravim miševima kao $i$ manju citotoksičnost ukupnih splenocita i NK ćelija, in vitro. Takode, detektovan je značajno veći broj CD11c+ dendritskih ćelija u slezini miševa sa tumorom, dok se broj aktiviranih CD80+CD86+ dendritskih ćelija nije značajno razlikovao u poređenju sa zdravim miševima, ukazujući na povećan broj nezrelih dendritskih ćelija u miševa sa tumorom. Rezultati ukazuju da je progresija 4 T1 karcinoma dojke povezana sa suprimiranim urodenim anti-tumorskim odgovorom.

Ključne reči: $4 T 1$ karcinom dojke, $B A L B / c$ miševi, NK ćelije, dendritske ćelije.

\section{INTRODUCTION}

Breast cancer is characterised by the development of metastasis in distant organs, such as the lungs, bones, liver and brain, and it is one of the leading causes of cancer deaths among women $(1,2)$. The role of innate immunity in breast cancer growth and progression remains unknown, but the role of the specific immune response has been extensively studied (3-4). The role of NK cells in immune surveillance as a first line of antitumor defence is well established (5-8). NK cell activity is variable during tumour progression and is related to clinical stage and disease outcome $(4,8-11)$. T cells are important effector cells against tumours, according to many studies on tumour models in mice (12-16). Cytotoxic CD8 ${ }^{+} \mathrm{T}$ cells kill tumour cells, while the anti-tumour immune response of $\mathrm{CD}^{+} \mathrm{T}$ cells can be polarised towards Th1, Th2 or Th17 type. The type- 1 immune response is characterised by the secretion of interferon-gamma (IFN- $\gamma$ ), which contributes to tumour rejection by stimulating the cytotoxic activity of $\mathrm{CD}^{+} \mathrm{T}$ and NK cells (17-20). In contrast, in the type- 2 anti-tumour immune response, interleukin-4 (IL-4), interleukin-5 (IL-5) and interleukin-10 (IL-10) suppress cellular immunity and therefore facilitate tumour growth and metastases (21-22). The role of the type-17 anti-tumour immune response has not been clarified. Interleukin-17 (IL-17), a hallmark Th17 
cell cytokine, is a potent mediator of inflammation in autoimmune diseases (23-24), but it has dual roles in antitumor immunity: not only can it promote tumour growth and metastasis by stimulating neoangiogenesis (25-27), IL-17 can also induce the cellular immunity responsible for tumour rejection (28-30). Dendritic cells (DCs) are part of the innate immune system involved in the activation and proliferation of tumour-specific T cells (31-33) and in enhancing the tumoricidal activity of NK cells (34-35). Immature DCs induce immunosuppressive CD4+ $\mathrm{T}$ cells (36-39), and tumour cells produce factors that could prevent DC maturation (40-41). Immature DCs are characterised by the weak expression of MHC II and co-stimulatory molecules with low IL-12 production and therefore have limited capacities to stimulate T cells (36-39). B cells contribute to antitumor immunity by secreting tumour-specific antibodies that facilitate the killing of tumour cells (42), but they can also induce a pro-angiogenic and pro-tumorigenic microenvironment that supports tumour growth (42).

In this study, using the 4T1 metastatic breast cancer model in BALB/C mice, we aimed to investigate anti-tumour innate immune mechanisms during the progression of primary tumours.

\section{MATERIALS AND METHODS}

\section{Mice}

In all of the experiments, we used female BALB/c mice that were 10-11 weeks old. The experiments were approved by the Animal Ethics Board of the Faculty of Medicine, University of Kragujevac, Serbia.

\section{$4 T 1$ tumour cells}

The mouse breast cancer cell line 4T1, which is syngeneic to the BALB/c background, was purchased from the American Type Culture Collection (ATCC, USA). 4T1 cells were maintained in Dulbecco's modified Eagle's medium supplemented with $10 \%$ foetal bovine serum, $2 \mathrm{mmol} / \mathrm{l} \mathrm{L}$ glutamine, $1 \mathrm{mmol} / \mathrm{l}$ penicillin-streptomycin, and $1 \mathrm{mmol} / \mathrm{l}$ mixed nonessential amino acids (Sigma, USA) (complete growth medium) and cultured under standard conditions as previously described (43). The number of viable tumour cells was determined by trypan blue exclusion, and only cell suspensions with $\geq 95 \%$ viable cells were used. Mice were orthotopically injected with $5 \times 10^{4} 4 \mathrm{~T} 1$ cells in the fourth mammary fat pad, as previously described (44).

\section{Cellular analysis of the spleen}

Mice were sacrificed on day 12 after tumour inoculation, and their spleens were removed. Single-cell suspensions were obtained from the spleens by mechanical dispersion through a cell strainer (BD Pharmingen, USA) in complete growth medium. Additionally, erythrocytes were removed from the splenocyte cell suspension by lysing solution (BD Pharmingen). After three washes, cells were resuspended in complete growth medium.

\section{Cell stimulation}

For analysis of CD107a expression, splenocytes were activated with phorbol 12-myristate 13-acetate (PMA, Sigma) (50 ng/ml) and ionomycin (500 ng/ml, Sigma) with GolgiStop (BD Pharmingen) as previously described $(43,45)$.

\section{Flow cytometry}

Single-cell suspensions from spleens were incubated with mAbs specific for mouse CD3, CD4, CD8, CD19, NKp46, CD107a, CD11c, CD80, and CD86 or isotype-matched controls (BD Pharmingen/BioLegend) and analysed with a FACSCalibur flow cytometer (BD). The gate used for FACS analysis was the mononuclear cell region in FSC/SSC plots (20000 events were acquired). Data were analysed using CELLQUEST (BD) and FlowJo (Tristar) software.

\section{NK cell separation}

NK cells were isolated from the spleen by magnetic cell sorting using FlowComp ${ }^{\mathrm{TM}}$ Mouse CD49b antibody (Invitrogen, USA), as previously described (43).

\section{$C D 8^{+}$T cell separation}

$\mathrm{CD}^{+} \mathrm{T}$ cells were isolated from spleens by depleting non$\mathrm{CD}^{+} \mathrm{T}$ cells $\left(\mathrm{CD} 4^{+} \mathrm{T}\right.$ cells, B cells, monocytes/macrophages, NK cells, dendritic cells, erythrocytes and granulocytes) using a mixture of monoclonal antibodies against non-CD8 ${ }^{+} \mathrm{T}$ cells (Invitrogen), as previously described (43). Isolated cells were highly enriched mouse CD8 ${ }^{+}$T cells (purity >90\%).

\section{Cytotoxicity assay}

The cytotoxic activity of splenocytes, enriched NK cells and enriched $\mathrm{CD}^{+} \mathrm{T}$ cells was measured using a $4 \mathrm{~h}$ MTT (3-(4,5-dimethylthiazol-2-yl)-2,5-diphenyltetrazolium bromide, Sigma) assay at various target-effector (T:E) ratios, as previously described (45). 4T1 tumour cells were used as targets. Data were expressed as the mean of triplicate wells \pm SEM. Cytotoxic activity was also presented by lytic units $\left(\mathrm{LU}_{20} / 10^{7}\right.$ cells), which were calculated from the means of triplicate percentages of killing obtained at four different T:E ratios (46).

\section{Statistical analysis}

The data were analysed using the SPSS statistical package, version 13. The two-tailed Student's t test was used. The normality of distribution was tested by the Kolmogorov-Smirnov test. The results were considered significantly different when $\mathrm{p}<0.05$ and highly significantly different when $\mathrm{p}<0.01$.

\section{RESULTS}

Twelve days after tumour inoculation, the percentage and total number of $\mathrm{CD} 19^{+} \mathrm{B}$ cells were increased while the frequency and number of $N K p 46^{+}$cells were decreased

We assessed the frequencies and the numbers of major lymphocyte populations in the spleens of naive and tumour-bearing mice at day 12 following tumour chal- 
A)

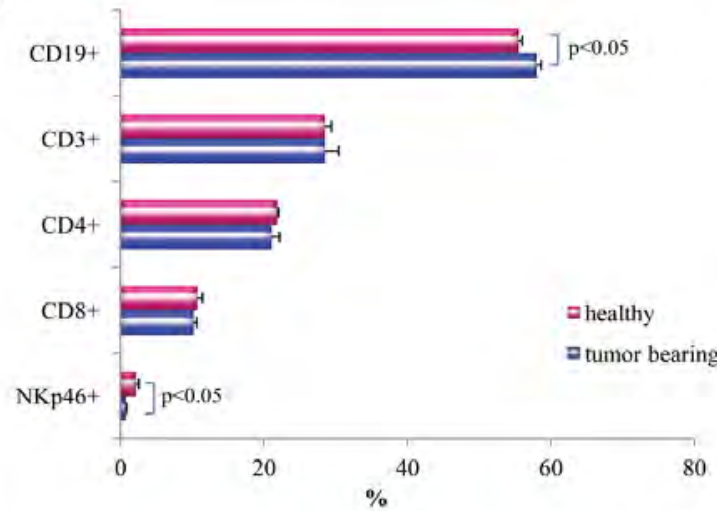

B)

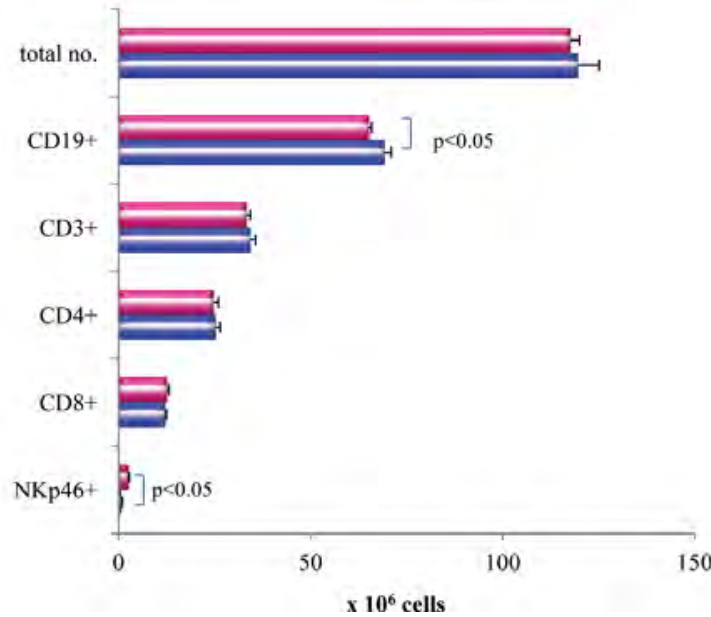

C)
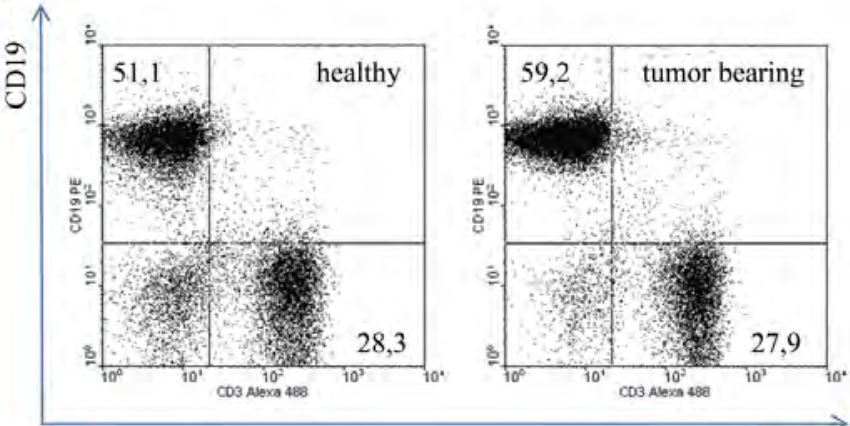

CD3
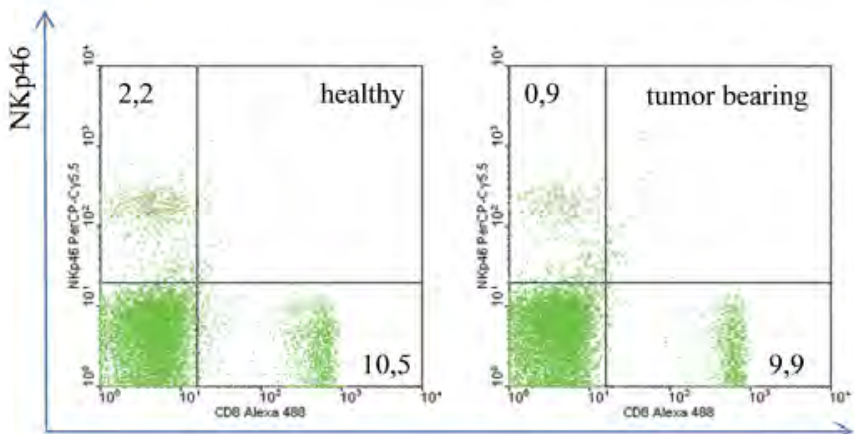

CD8

Figure 1. FACS analysis of splenocytes from tumour-bearing versus tumour-naïve mice

A-B) The total cell number of splenocytes was determined in healthy and tumour-bearing mice on day 12 after tumour inoculation. Percentages and total numbers of CD19+, CD3+, CD4+ CD8+ and NKp46+ cells were determined by staining splenocytes with fluorochrome-labelled mAbs and analysing them with a FACSCalibur flow cytometer.

C) Representative flow cytometry dot plots show percentages of CD19+, CD3+, CD8+ and NKp46+ cells in spleens from healthy and tumour-bearing mice. The gate used for analysis was the mononuclear cell region in FSC/SSC plots. Data are presented as the mean \pm SEM of two separate experiments, each carried out with four mice per group. Statistical significance was tested by Student's t-test.

lenge. The total number of splenocytes was not significantly changed in tumour-bearing mice compared with healthy mice (Fig. 1B). The frequency and total number of splenic CD19+ $\mathrm{B}$ cells were significantly increased after tumour inoculation $(\mathrm{p}<0.05)$. There was no difference in the percentage or total number of $\mathrm{CD}^{+}, \mathrm{CD}^{+}$or $\mathrm{CD}^{+}$ cells (Fig. 1A and $1 \mathrm{~B}$ ) between tumour-bearing and naïve mice. 4T1 tumour administration markedly reduced the percentages and numbers of NKp46+ cells $(\mathrm{p}<0.05)$, as shown in Figs. 1A and 1B.

The cytotoxic activity of NK cells but not CD8 ${ }^{+}$T cells was suppressed after tumour inoculation

On day 12 of tumour progression, the in vitro cytotoxic activity of total splenocytes was decreased (Fig. 2). We subsequently isolated NK cells $\left(\mathrm{CD}_{4} 9 \mathrm{~b}^{+}\right)$and $\mathrm{CD} 8^{+} \mathrm{T}$ cells from spleens and assessed their antitumor cytotoxic- ity. The cytotoxic activity of $\mathrm{CD}^{+} \mathrm{T}$ cells was higher after tumour inoculation $(\mathrm{p}<0.05$; Fig. 2$)$, while the cytotoxicity of NK cells derived from spleens of tumour-bearing mice was significantly lower compared with healthy animals. In addition, activated CD107 $\mathrm{a}^{+} \mathrm{NK}$ cells were less frequent in tumour-bearing mice, while the percentage of CD107 $\mathrm{a}^{+} \mathrm{CD} 8^{+} \mathrm{T}$ cells was higher at the same time point (both $\mathrm{p}<0.05$; Fig. 2).

\section{The frequency and total number of $\mathrm{CD} 11 c^{+}$dendritic} cells were increased after tumour induction

After 12 days of 4T1 tumour inoculation, the percentage and number of CD11c $\mathrm{c}^{+} \mathrm{DCs}$ were higher in spleens from tumour-bearing mice (both $\mathrm{p}<0.05$; Fig. 3 ). Analyses of the activation status of these cells revealed no significant difference in frequencies or numbers of activated $\mathrm{CD} 80^{+} \mathrm{CD} 86^{+}$dendritic cells between healthy and tumour-bearing mice (Fig. 3). 

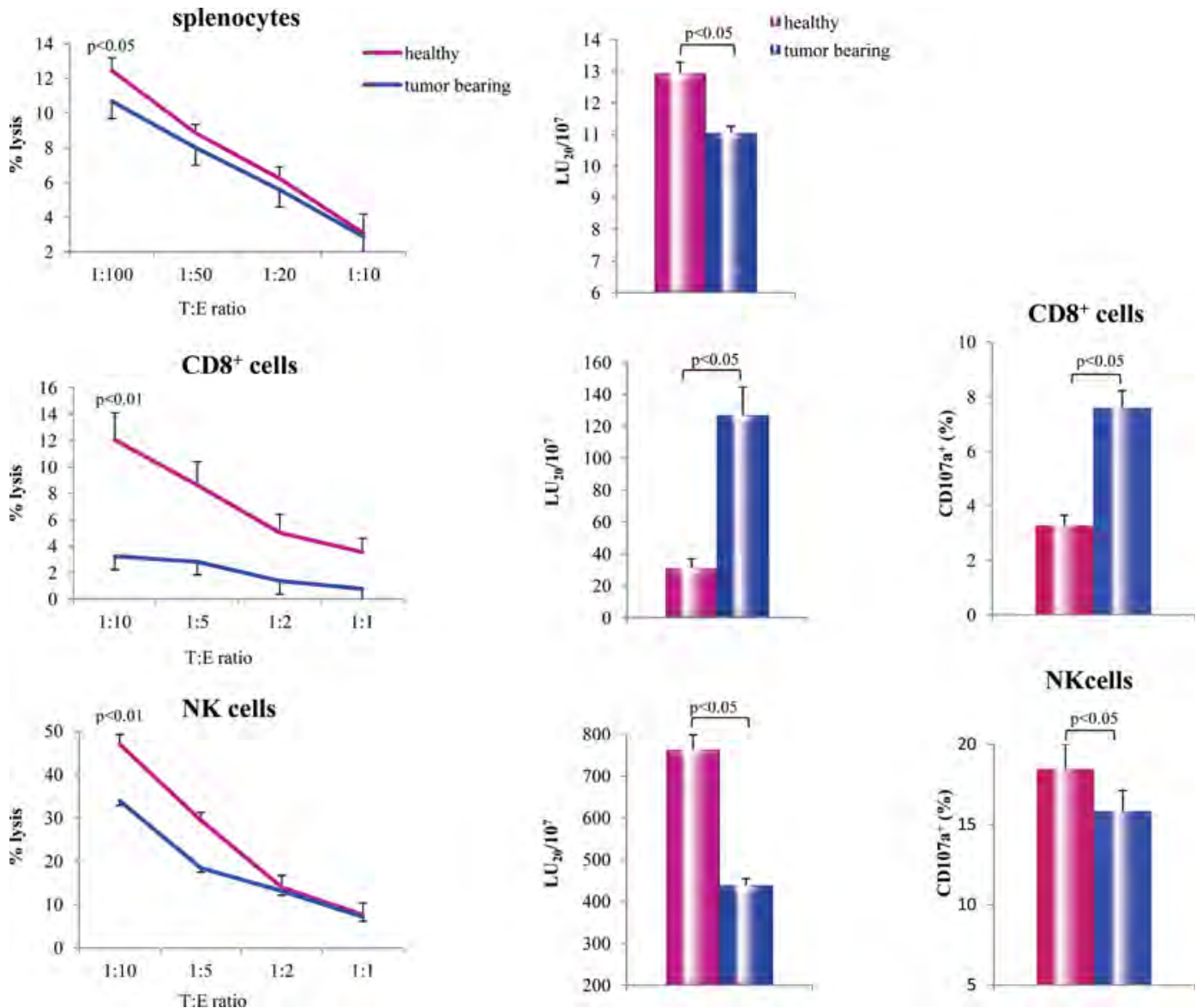

Figure 2. Cytotoxic activity of total splenocytes, CD8+ T cells and NK cells

The cytotoxicity of splenocytes, isolated CD8+ T cells and NK cells was tested with a 4-h MTT assay against 4T1 cell targets at day 12 after tumour inoculation. The data are presented as the mean percentages of specific cytotoxicity and as LU20/107 effector cells, which was calculated on the basis of mean percentages of killing at four different E:T ratios and percentages of effector cells found in the spleen. The cytotoxic capacity of NK and CD8+ T cells was also determined by flow cytometric analysis of CD107a expression on NKp46+ and CD8+ cells. The gate used for analysis was the mononuclear cell region in FSC/SSC plots. Data are means \pm SEM of two individual experiments, each carried out with four mice per group. Statistical significance was tested by Student's t-test.

A)

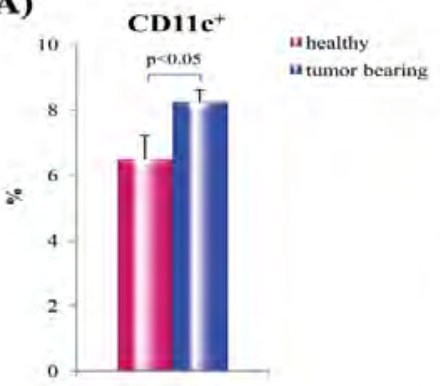

B)

Figure 3. Frequency, number and functional phenotype of CD11c+ dendritic cells derived from the spleen

A) The percentage and total number of $\mathrm{CD} 11 \mathrm{c}+$ dendritic cells were determined with a FACSCalibur flow cytometer before and at day 12 following $4 \mathrm{~T} 1$ tumour challenge. The results are presented as the mean \pm SEM of 8 mice per group. B) The percentage and total number of CD80+CD86+ dendritic cells were also analysed by flow cytometry. The results are presented as the mean \pm SEM of 4 mice per group. Statistical significance was determined by Student's t-test.

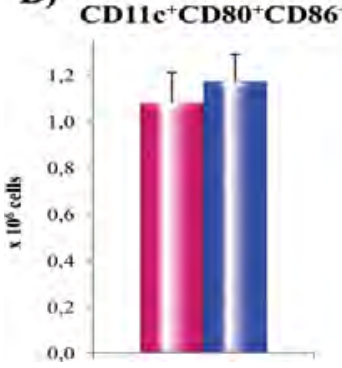

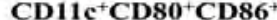

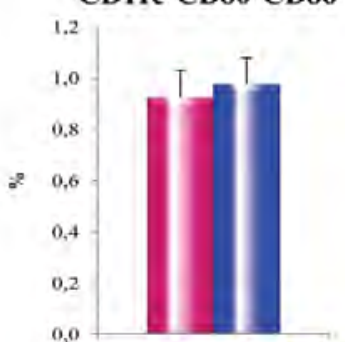




\section{DISCUSSION}

In this study, we report that 12 days after the inoculation of 4T1 mammary carcinoma cells, the percentage and number of CD19+ $\mathrm{B}$ cells in spleens were significantly increased, while the number and cytotoxic activity of NK cells were decreased (Fig. 1). Additionally, the frequency and number of $\mathrm{CD} 11 \mathrm{c}^{+}$dendritic cells were higher in spleens from tumour-bearing mice compared with naïve mice, but the frequency of activated dendritic cells in both groups was not significantly different (Fig. 3).

The increased frequency and number of $\mathrm{CD} 19^{+} \mathrm{B}$ cells in spleens of tumour-bearing BALB/c mice could be the result of Th2 polarisation, which implicates the predominance of the type-2 antitumor immune response (22). However, there is evidence that the type- 17 response can also induce $\mathrm{B}$ cell proliferation and the formation of germinal centres (47). Several studies have shown that B cell proliferation in lymph organs correlates with tumour progression (48-49). Furthermore, we found no difference in the percentage or number of splenic T cells and $\mathrm{CD} 4^{+}$and $\mathrm{CD}^{+}$subpopulations, indicating weak or no activity of adaptive cellular immunity, on day 12 after tumour challenge (Fig 1).

We also detected the decreased cytotoxicity of total splenocytes isolated from tumour-bearing mice (Fig. 2). To determine which cell population was responsible for this phenomenon, we isolated $\mathrm{NK}$ and $\mathrm{CD}^{+} \mathrm{T}$ cells and tested their antitumor cytotoxic activity in vitro at day 12 . We found enhanced cytotoxicity of $\mathrm{CD}^{+} \mathrm{T}$ cells (Fig. 2). However, the cytotoxic activity of NK cells was significantly decreased at the same time point, which contributed to the lower cytotoxic activity of total splenocytes (Fig. 2). During the cytotoxic killing of tumour cells, NK cells and $\mathrm{CD} 8^{+} \mathrm{T}$ cells rapidly release granules containing perforin and granzymes into the immunological synapse, thereby inducing the death of target cells (50). Lysosomalassociated membrane protein-1 (LAMP-1), also known as CD107a, is a marker of cytotoxic degranulation, as it lines the membrane of these granules (51). CD107a can be used as an indirect indicator of the cytotoxic capacity of NK and $\mathrm{CD}^{+} \mathrm{T}$ cells (52). In line with these findings, we found a higher frequency of activated $\mathrm{CD} 8^{+} \mathrm{CD} 107 \mathrm{a}^{+} \mathrm{T}$ cells while activated $\mathrm{NKp} 46^{+} \mathrm{CD} 107 \mathrm{a}^{+} \mathrm{NK}$ cells were less frequent in spleens from tumour-bearing mice (Fig. 2). Several studies have revealed lower cytotoxic activity of NK cells in patients with breast cancer compared with healthy controls, with a negative correlation of NK cell lytic activity with lymph node progression of disease (9).

Functional maturation and the activity of NK and T cells appear to be dependent on the functional phenotype of DCs (53). We showed that tumour inoculation led to an increase in the frequencies and numbers of CD $11 \mathrm{c}^{+} \mathrm{DCs}$ in spleens (Fig. 3). During maturation/activation, DCs express more MHC class II and CD80 and CD86 co-stimulatory molecules, all of which have T-cell stimulatory capacity. However, there was no difference in the percentage or total number of fully functional CD $80^{+} \mathrm{CD} 86^{+} \mathrm{DCs}$ in tumour-bearing mice compared with healthy animals (Fig. 3 ). Thus, it could be assumed that 12 days after tumour inoculation, the functional maturation of dendritic cells was absent. The interaction of mature DCs with NK and T cells is essential for the tumoricidal activity of these effector cells, while immature DCs can induce immunosuppressive activity of the same effector cells (34-35).

Taken together, we demonstrate that 12 days after inoculation with 4T1 mammary breast carcinoma, NK cell cytotoxicity was markedly reduced, and DCs were not activated after tumour challenge. These findings suggest a suppressed innate anti-tumour immune response in mammary carcinoma-bearing BALB/c mice.

\section{ACKNOWLEDGEMENTS}

We thank Milan Milojevic for excellent technical assistance. This work was funded by grants from the Serbian Ministry of Science and Technological Development, Serbia (Grants OP 175071 and OP 175069) and by the Medical Faculty, University of Kragujevac, Serbia (Grant JP 25/10).

\section{REFERENCES}

1. Ferlay J, Parkin DM, Sreliarova-Foucher E. Estimates of cancer incidence and mortality in Europe in 2008. Eur J Cancer 2010; 46: 765-781.

2. Lu X, Kang Y. Organotropism of breast cancer metastasis. J Mammary Gland Biol Neoplasia 2007; 12: 153-162.

3. Vujanovic NL, Basse P, Herberman RB and Whiteside TL. Antitumor functions of natural killer cells and control of metastasis. Methods 1996; 9: 394-408.

4. Standish LJ, Sweet ES, Novack J, Wenner CA, Bridge C, Nelson A, Martzen M, Torkelson C. Breast cancer and the immune system. J Soc Integr Oncol 2008; 6: 158-168.

5. Riccardi C, Santoni A, Barlozzari T, Puccetti P, Herberman RB. In vivo natural reactivity of mice against tumor cells. Int J Cancer 1980; 25: 475-486.

6. Wiltrout RH, Herberman RB, Zhang SR, Chirigos MA, Ortaldo JR, Green KM Jr, Talmadge JE. Role of organ-associated NK cells in decreased formation of experimental metastases in lung and liver. J Immunol 1985; 134: 4267-4275.

7. Gorelik E, Herberman RB. Radioisotope assay for evaluation of in vivo natural cell-mediated resistance of mice to local transplantation of tumor cells. Int J Cancer 1981; 27: 709-720.

8. Gorelik E, Wiltrout RH, Okumura K, Habu S, Herberman RB. Role of NK cells in the control of metastatic spread and growth of tumor cells in mice. Int J Cancer 1982; 30: 107-112.

9. Strayer DR, Carter WA, Mayberry SD et al. Low natural cytotoxicity of peripheral blood mononuclear cells in individuals with high familial incidences of cancer. Cancer Res 1984; 44: 370-374. 
10. Hacene K, Desplaces A, Brunet M, Lidereau R, Bourguignat A, Oglobine J. Competitive prognostic value of clinicopathologic and bioimmunologic factors in primary breast cancer. Cancer 1986; 57: 245-250.

11. Mohanty I, Nayak M, Nanda BK. Cell mediated immune status in carcinoma breast. Indian J Pathol Microbiol 1991; 34: 1-6.

12. Ward PL, Koeppen HK, Hurteau T et al. Major histocompatibility complex class I and unique antigen expression by murine tumors that escaped from CD8+ T-cell-dependent surveillance. Cancer Res 1990; 50: 3851-3858.

13. Fearon ER, Pardoll DM, Itaya T et al. Interleukin-2 production by tumor cells bypasses $\mathrm{T}$ helper function in the generation of an antitumor response. Cell 1990; 60: 397-403.

14. Golumbek PT, Lazenby AJ, Levitsky HI et al. Treatment of established renal cancer by tumor cells engineered to secrete interleukin-4. Science 1991; 254: 713-716.

15. Dranoff G, Jaffee E, Lazenby A et al. Vaccination with irradiated tumor cells engineered to secrete murine granulocyte-macrophage colony-stimulating factor stimulates potent, specific, and long-lasting anti-tumor immunity. Proc Natl Acad Sci USA 1993; 90: 3539-3543.

16. Lin KY, Guarnieri FG, Staveley-O'Carroll KF et al. Treatment of established tumors with a novel vaccine that enhances major histocompatibility class II presentation of tumor antigen. Cancer Res 1996; 56: 21-26.

17. Dobrzanski MJ, Reome JB, Hylindand JC, Rewers-Felkins KA. CD8-Mediated Type 1 Antitumor Responses Selectively Modulate Endogenous Differentiated and Nondifferentiated T Cell Localization, Activation, and Function in Progressive Breast Cancer. J Immunol 2006; 177: 8191-8201.

18. Hung K, Hayashi R, Lafond-Walker A, Lowenstein C, Pardoll D and Levitsky $\mathrm{H}$. The central role of CD4+ T cells in the antitumor immune response. J Exp Med 1998; 188: 2357-2368.

19. Ito N, Nakamura H, Tanaka Y, and Ohgi S. Lung carcinoma: analysis of T-helper type 1 and 2 cells and T-cytotoxic type 1 and 2 cells by intracellular cytokine detection with flow cytometry. Cancer 1999; 85: 2359-2367.

20. Nishimura T, Nakui M, Sato M, Iwakabe K, Kitamura $\mathrm{H}$, Sekimoto $\mathrm{M}$ et al. The critical role of Th1-dominant immunity in tumor immunology. Cancer Chemother Pharmacol 2000; 46: 52-61.

21. Chan WL, Pejnovic N, Lee CA and Al-Ali NA. Human Il-18 receptor and ST2L are stable and selective markers for the respective type 1 and type 2 circulating tymphocytes. J. Immunol 2001; 167: 1238-1244.

22. Ellyard JI, Simson L, Parish CR. Th2-mediated anti-tumour immunity: friend or foe? Tissue Antigens 2007; 70: 1-11.

23. Tzartos JS, Friese MA, Craner MJ, Palace J, Newcombe J, Esiri MM, Fugger L. Interleukin-17 production in central nervous system-infiltrating $\mathrm{T}$ cells and glial cells is associated with active disease in multiple sclerosis. Am J Pathol 2008; 172: 146-155.
24. Steinman L. A brief history of $\mathrm{T}_{\mathrm{H}} 17$, the first major revision in the $\mathrm{T}_{\mathrm{H}} 1 / \mathrm{T}_{\mathrm{H}} 2$ hypothesis of $\mathrm{T}$ cell-mediated tissue damage. Nat Med 2007; 13: 139-145.

25. Tartour E, Fossiez F, Joyeux I, Galinha A, Gey A, Claret E, Sastre- Garau X, Couturier J, Mosseri V, Vives V, Banchereau J, Fridman WH, Wijdenes J, Lebecque S, Sautès-Fridman C: Interleukin 17, a T-cell-derived cytokine, promotes tumorigenicity of human cervical tumors in nude mice. Cancer Res 1999; 59: 3698-3704.

26. Numasaki M, Fukushi J, Ono M, Narula SK, Zavodny PJ, Kudo T, Robbins PD, Tahara H, Lotze MT: Interleukin-17 promotes angiogenesis and tumor growth. Blood 2003; 101: 2620-2627.

27. Kato T, Furumoto H, Ogura T, Onishi Y, Irahara M, Yamano S, Kamada M, Aono T: Expression of IL-17 mRNA in ovarian cancer. Biochem Biophys Res Commun 2001; 282: 735-738.

28. Hirahara N, Nio Y, Sasaki S, Minari Y, Takamura M, Iguchi C, Dong M, Yamasawa K, Tamura K: Inoculation of human interleukin-17 gene-transfected Meth-A fibrosarcoma cells induces $\mathrm{T}$ celldependent tumor-specific immunity in mice. Oncology 2001; 61: 79-89.

29. Hirahara N, Nio Y, Sasaki S, Takamura M, Iguchi C, Dong M, Yamasawa K, Itakura M, Tamura K: Reduced invasiveness and metastasis of Chinese hamster ovary cells transfected with human interleukin-17 gene. Anticancer Res 2000; 20: 3137-3142.

30. Benchetrit F, Ciree A, Vives V, Warnier G, Gey A, Sautès-Fridman C, Fossiez F, Haicheur N, Fridman WH, Tartour E: Interleukin-17 inhibits tumor cell growth by means of a T-cell-dependent mechanism. Blood 2002; 99: 2114-2121.

31. Banchereau J, Steinman RM. Dendritic cells and the control of immunity. Nature 1998; 392: 245-252.

32. Schuler G, Schuler-Thurner B, Steinman RM. The use of dendritic cells in cancer immunotherapy. Curr Opin Immunol 2003; 15: 138-147.

33. Schuler G, Steinman RM. Dendritic cells as adjuvants for immune-mediated resistance to tumors. J Exp Med 1997; 186: 1183-1187.

34. Fernandez NC, Lozier A, Flament C, Ricciardi-Castagnoli P, Bellet D, Suter M, Perricaudet M, Tursz T, Maraskovsky E, Zitvogel L. Dendritic cells directly trigger NK cell functions: Cross-talk relevant in innate antitumor immune responses in vivo. Nat Med 1999; 5: 405-411.

35. Gustafsson K, Ingelsten M, Bergqvist L, Nyström J, Andersson B, Karlsson-Parra A. Recruitment and activation of natural killer cells in vitro by a human dendritic cell vaccine. Cancer Res 2008; 68: 5965-5971.

36. Almand B, Clark JI, Nikitina E, van Beynen J, English NR, Knight SC, Carbone DP, Gabrilovich DI. Increased production of immature myeloid cells in cancer patients: A mechanism of immunosuppression in cancer. J Immunol 2001; 166: 678-689. 
37. Almand B, Resser JR, Lindman B, Nadaf S, Clark JI, Kwon ED, Carbone DP, Gabrilovich DI. Clinical significance of defective dendritic cell differentiation in cancer. Clin Cancer Res 2000; 6: 1755-1766.

38. Gabrilovich DI, Velders MP, Sotomayor EM, Kast WM. Mechanism of immune dysfunction in cancer mediated by immature Gr-1+ myeloid cells. J Immunol 2001; 166: 5398-5406.

39. Young MR, Wright MA, Lozano Y, Prechel MM, Benefield J, Leonetti JP, Collins SL, Petruzzelli GJ. Increased recurrence and metastasis in patients whose primary head and neck squamous cell carcinomas secreted granulocyte-macrophage colony-stimulating factor and contained CD34+ natural suppressor cells. Int J Cancer 1997; 74: 69-74.

40. Yang L, Carbone DP. Tumor-host immune interactions and dendritic cell dysfunction. Adv Cancer Res 2004; 92: 13-27.

41. Pinzon-Charry A, Maxwell T, López JA. Dendritic cell dysfunction in cancer: A mechanism for immunosuppression. Immunol Cell Biol 2005; 83: 451-461.

42. DeNardo DG and Coussens LM. Inflammation and breast cancer Balancing immune response: crosstalk between adaptive and innate immune cells during breast cancer progression. Breast Cancer Research 2007; 9: 212.

43. Jovanovic I, Radosavljevic G, Mitrovic M, Lisnic Juranic V, McKenzie ANJ, Arsenijevic N, Jonjic S. and Lukic ML. ST2 Deletion Enhances Innate and Acquired Immunity to Murine Mammary Carcinoma. Eur J Immunol 2011; 41: 1902-1912.

44. Jovanović I, Radosavljević G, Pavlović S, Zdravković N, Martinova K, Knežević M, Živić D, Lukić ML, Arsenijević N. Th-17 cells as novel participant in immunity to breast cancer. Serb J Exp Clin Res 2010; 11: 7-17.

45. Radosavljevic G, Jovanovic I, Majstorovic I, Mitrovic M, Lisnic VJ, Arsenijevic N, Jonjic S, Lukic ML. Deletion of galectin-3 in the host attenuates metastasis of murine melanoma by modulating tumor adhesion and NK cell activity. Clin Exp Metastasis 2011; 28: 451-462.

46. Janjic BM, Lu G, Pimenov A, Whiteside TL, Storkus WJ and Vujanovic NL. Innate direct anticancer effector function of human immature dendritic cells. I. Involvement of an apoptosis-inducing pathway. J Immunol 2002; 168: 1823-1830.

47. Hsu HC, Yang P, Wang J, Wu Q, Myers R, Chen J, Yi J, Guentert T, Tousson A, Stanus AL, Le TV, Lorenz RG, $\mathrm{Xu} \mathrm{H}$, Kolls JK, Carter RH, Chaplin DD, Williams RW, Mountz JD. Interleukin 17-producing $\mathrm{T}$ helper cells and interleukin 17 orchestrate autoreactive germinal center development in autoimmune BXD2 mice. Nat Immunol 2008; 9: 166-175.

48. Morton BA, Ramey WG, Paderon H, Miller RE. Monoclonal antibody-defined phenotypes of regional lymph node and peripheral blood lymphocyte subpopulations in early breast cancer. Cancer Res 1986; 46: 2121-2126.

49. Wernicke M. Quantitative morphologic assessment of immunoreactivity in regional lymph nodes of patients with carcinoma of the breast. Surg Gynecol Obstet 1975; 140: 919-924.

50. Kauschke E, Komiyama K, Moro I, Eue I, König S, Cooper EL. Evidence for perforin-like activity associated with earthworm leukocytes. Zoology (Jena) 2001; 104: 13-24.

51. Winchester BG. Lysosomal membrane proteins. Eur J Paediatr Neurol 2001; 5: 11-9.

52. Betts MR, Brenchley JM, Price DA, De Rosa SC, Douek DC, Roederer M, Koup RA. Sensitive and viable identification of antigen-specific CD8+ T cells by a flow cytometric assay for degranulation. J Immunol Methods 2003; 281: 65-78.

53. Foti M, Granucci F and Ricciardi-Castagnoli P. A central role for tissue-resident dendritic cells in innate responses. Trends Immunol 2004; 25: 650-654. 